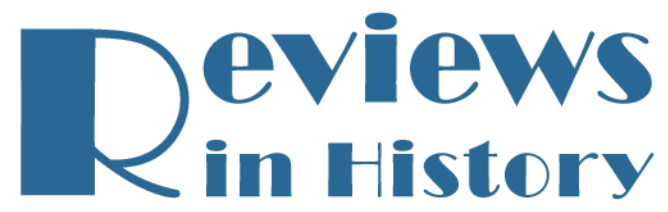

Published on Reviews in History (https://reviews.history.ac.uk)

\title{
INTERVIEW: Professor Jan Plamper talks to Dr Jordan Landes
}

Review Number: 1753

Publish date: Thursday, 16 April, 2015

Author: Jan Plamper

ISBN: 9780199668335

Date of Publication: 2015

Price: $£ 35.00$

Pages: 368pp.

Publisher: Oxford University Press

Publisher url: http://ukcatalogue.oup.com/product/9780199668335.do

Place of Publication: Oxford

Reviewer: Jordan Landes

In the latest of our occasional Reviews in History podcast series, Dr Jordan Landes talks to Professor Jan Plamper about his new work on the history of emotions, a subject which he has memorably described as a 'rocket taking off'.

Jan Plamper is Professor of History at Goldsmiths, University of London.

Jordan Landes is history subject librarian at Senate House Library, University of London.

Listen to the interview here [2].

Source URL:https://reviews.history.ac.uk/review/1753

\section{Links}

[1] https://reviews.history.ac.uk/item/132445

[2] http://podcast.ulcc.ac.uk/accounts/SAScasts/ReviewsinHistory/Plampernoisereducedandmerged.mp3 